AperTO - Archivio Istituzionale Open Access dell'Università di Torino

\title{
Rate of Adverse Effects of Medium- to High-Dose Glucocorticoid Therapy in Systemic Lupus Erythematosus: A Systematic Review of Randomized Control Trials
}

\section{This is the author's manuscript}

Original Citation:

Availability:

This version is available http://hdl.handle.net/2318/1635621

since 2019-02-13T13:14:12Z

Published version:

DOI:10.1007/s40261-017-0518-z

Terms of use:

Open Access

Anyone can freely access the full text of works made available as "Open Access". Works made available under a Creative Commons license can be used according to the terms and conditions of said license. Use of all other works requires consent of the right holder (author or publisher) if not exempted from copyright protection by the applicable law. 
This is the author's final version of the contribution published as:

Sciascia, Savino; Mompean, Elisa; Radin, Massimo; Roccatello, Dario; Cuadrado, Maria J.. Rate of Adverse Effects of Medium- to High-Dose Glucocorticoid Therapy in Systemic Lupus Erythematosus: A Systematic Review of Randomized Control Trials. CLINICAL DRUG

INVESTIGATION. 37 (6) pp: 1-6.

DOI: $10.1007 / \mathrm{s} 40261-017-0518-\mathrm{z}$

The publisher's version is available at:

http://link.springer.com/10.1007/s40261-017-0518-z

When citing, please refer to the published version.

Link to this full text:

http://hdl.handle.net/ 
Rate of adverse events of medium-to high dose glucocorticoid therapy in Systemic Lupus

Erythematous: a systematic review 


\section{$\underline{\text { Abstract }}$}

The efficacy of glucocorticoids (GCs) in treating Systemic Lupus Erythematous (SLE) is beyond doubt. However, GCs-related adverse events (AEs) are multiples and serious. Despite the current available evidences suggesting to reduce daily doses of prednisone $<7.5 \mathrm{mg} /$ day, or even to withdraw it, in the real-life practice, it is not uncommon to see patients receiving medium doses (up to $30 \mathrm{mg} / \mathrm{day}$ prednisone or equivalent) or high doses ( $\geq 30 \mathrm{mg} /$ day). In this systematic review we assessed the rate of AEs related to medium or high dose of GCs in patients with SLE, analysing randomised control trials with at least one of the treatment groups including GCs alone at medium doses or high doses. We found a rate of 9/100patients/year for hyperglycaemias/diabetes, 25/100patients/year infections, and 12/100patients/year for avascular necrosis of the hip. Interestingly, when adjusting for CGs dose and treatment duration, we observed no difference in terms of AEs rate comparing patients receiving medium Vs. high doses. In the era when treat-to-target strategies have been proposed in order to control SLE disease activity, improve health-related quality of life, and reduce morbidity and mortality, using GCs in a more restrictive way should be a goal to prevent major complications in patients with SLE. 


\section{INTRODUCTION}

Glucocorticoids (GCs) are among the most potent immunosuppressive and anti-inflammatory drugs. Their efficacy in treating Systemic Lupus Erythematous (SLE) is beyond doubt. However, GC-related side effects are multiples and serious. Indeed, prednisone use has been consistently shown to increase irreversible damage in lupus patients, a major predictor of morbidity and mortality [1]. Despite the current available evidences suggesting to reduce daily doses of prednisone $<7.5 \mathrm{mg} / \mathrm{day}$, or even to withdraw it, sometimes physicians might struggle in achieving this goal. Among others, Gladman et al. when reporting on the course of an inception SLE cohort prospectively followed-up of at least 15 years showed that overall $87.7 \%$ of patients received GCs, at a mean maximum dose of $37.7 \mathrm{mg} / \mathrm{day}$ [2]. Similarly, in the real-life practice, it is not uncommon to see patients receiving medium doses (up to 30 $\mathrm{mg} /$ day) or high doses ( $\geq 30 \mathrm{mg} /$ day). Adverse effects (AEs) of GC therapy, such as increased risk of infection, avascular osteonecrosis, osteoporosis, myopathy, diabetes mellitus or cushingoid features, as well as skin bruising and cataracts are known and have been well described, especially in studies conducted when GCs were among the few therapeutic tools for SLE management [1]. However, quantifying the risk of AEs related to medium or high dose of GCs is still challenging, especially in an era when patients are rarely receiving GCs alone.

\section{MATERIALS and METHODS}

When attempting to assess the rate of AEs related to medium or high dose of GCs in patients with SLE, using a pre-defined protocol, we systematically reviewed the literature selecting studies for evaluation when they met all of the following criteria: (i) Randomized Control Trials (RCTs), (ii) enrolled adult patients with SLE, (iii) at least one of the treatment groups includes corticosteroids alone at medium doses (up to $30 \mathrm{mg} /$ day prednisone or equivalent) or high doses ( $\geq 30 \mathrm{mg} /$ day prednisone or equivalent), (iii) reporting rate of GC-related side effects (including hypertension, diabetes, reduction in bone mass index/aseptic osteonecrosis). We searched the MEDLINE, EMBASE and CINAHL databases from their inception (starting in 1950) to December 2016. Medical subject headings (MeSH) terms used in the MEDLINE database search included 'systemic lupus erythematosus', 
'corticosteroids', 'glucocorticoids'. Index terms were modified appropriately for the other databases. The Cochrane Library (the Cochrane Central Register of Controlled Trials and the Cochrane Database for Systematic Reviews) was also searched. This was supplemented by manually searching bibliographies of these articles and of previously published reviews.

Potential studies identified with the above search strategy were exported to an electronic reference management software program (RefWorks v.2.0). Duplicate studies were identified and removed using the filter functions "exact duplicates" and "close duplicates."

Quality assessments of the suitable RCTs and data extraction from them were done independently by two reviewers (E.M. and S.S.). In case of disagreement, consensus was aimed for and if it was not achieved, a third reviewer (M.J.C.) gave final judgment. It was pre-determined that the corresponding author of an included RCT would only be contacted if any data/information relevant to this metaanalysis was found missing in the published RCT.

We abstracted data for the AEs from every paper and entered them into a Microsoft Excel database. For the 8 retained studies [3-10], the extracted data included study characteristics (setting, duration, design, treatment/intervention, patients characteristic, AES rate and details).

\section{RESULTS AND DISCUSSION}

Out of one-hundred and two screened studies, a total of 8 RTCs [3-10] met the inclusion criteria, including 182 SLE patients receiving GCs alone at medium doses (up to $30 \mathrm{mg} /$ day prednisone or equivalent) or high doses ( $\geq 30 \mathrm{mg} /$ day prednisone or equivalent). Study details, patients characteristics and treatments protocols are shown in Table 1. AEs for each study are described in Table 2. When pooling together the adverse events reported in studies and adjusting for treatment duration, we found a rate of 9/100patients/year for hyperglycaemias/diabetes, 25/100patients/year infections, and 12/100patients/year for avascular necrosis of the hip. Among the studies reporting the type of infection, respiratory tract and herpes zoster infections seemed the most frequently occurred. When adjusting for CGs dose (meant as prednisone equivalent, calculated according to Shimmer et al. [11]) and treatment duration, we observed no difference in terms of AEs rate comparing patients 
receiving medium Vs. high doses. This observation is in line with the ideas that GCs-related AEs should be considered according to the level of activation of the genomic and non-genomic ways (low doses , up to $7.5 \mathrm{mg} /$ day Vs. medium-high doses, equal or higher than $30 \mathrm{mg} /$ day)[12]. This aspect should be kept in mind when a steroid tapering scheme is planned, as it should aim to achieve dose $<30 \mathrm{mg} / \mathrm{dl}$ to really impact on the rate of GCs-related AEs.

Every effort should be made to avoid GC side effects. It should be remembered that medium to high GCs doses are not the therapy of lupus, but part of the treatment of few severe lupus manifestations. Concomitant use of immunosuppressive agents [13], biological drugs [14,15] and anti-malarials [16] may help keep daily doses of prednisone $<7.5 \mathrm{mg} /$ day, or even to withdraw it. In the era when treatto-target strategies have been proposed in order to control disease activity, improve health-related quality of life, and reduce morbidity and mortality, using GCs in a more restrictive way should be a goal to prevent major complications in patients with SLE. 


\section{REFERENCES}

1. Ruiz-Irastorza G, Danza A, Khamashta M. Glucocorticoid use and abuse in SLE. Rheumatology 2012; 51: 1145-53.

2. Gladman DD, Urowitz MB, Rahman P, Ibañez D, Tam L-S. Accrual of organ damage over time in patients with systemic lupus erythematosus. J Rheumatol 2003; 30: 1955-9.

3. Austin HA, Illei GG, Braun MJ, Balow JE. Randomized, controlled trial of prednisone, cyclophosphamide, and cyclosporine in lupus membranous nephropathy. J Am Soc Nephrol 2009; 20: 901-11.

4. Barile-Fabris L, Ariza-Andraca R, Olguín-Ortega L, et al. Controlled clinical trial of IV cyclophosphamide versus IV methylprednisolone in severe neurological manifestations in systemic lupus erythematosus. Ann Rheum Dis 2005; 64: 620-5.

5. Barron KS, Person DA, Brewer EJ, Beale MG, Robson AM. Pulse methylprednisolone therapy in diffuse proliferative lupus nephritis. J Pediatr 1982; 101: 137-41.

6. Belmont HM, Kitsis E, Skovron ML, Buyon J, McCullagh E, Abramson S. Misoprostol and Prednisone Treatment of Lupus Nephritis. Am J Ther 1995; 2: 928-32.

7. Boumpas DT, Austin HA, Vaughn EM, et al. Controlled trial of pulse methylprednisolone versus two regimens of pulse cyclophosphamide in severe lupus nephritis. Lancet (London, England) 1992; 340: 741-5.

8. Chan TM, Li FK, Tang CSO, et al. Efficacy of Mycophenolate Mofetil in Patients with Diffuse Proliferative Lupus Nephritis. N Engl J Med 2000; 343: 1156-62.

9. Edwards JC, Snaith ML, Isenberg DA. A double blind controlled trial of methylprednisolone infusions in systemic lupus erythematosus using individualised outcome assessment. Ann Rheum Dis 1987; 46: 773-6.

10. Gourley MF, Austin HA, Scott D, et al. Methylprednisolone and cyclophosphamide, alone or in combination, in patients with lupus nephritis. A randomized, controlled trial. Ann Intern Med 1996; 125: 549-57.

11. Shimmer BP, Funder JW et al. ACTH, Adrenal Steroids, and Pharmacology of the Adrenal Cortex. In: Goodman \& Gilman's The Pharmacological Basis of Therapeutics, $12 e$.

12. Buttgereit F, Straub RH, Wehling M, Burmester G-R. Glucocorticoids in the treatment of rheumatic diseases: an update on the mechanisms of action. Arthritis Rheum 2004; 50: 3408-17.

13. Fortin PR, Abrahamowicz M, Ferland D, et al. Steroid-sparing effects of methotrexate in systemic lupus erythematosus: a double-blind, randomized, placebo-controlled trial. Arthritis Rheum 2008; 59: 1796-804.

14. Roccatello D, Sciascia S, Di Simone D, et al. New insights into immune mechanisms underlying response to Rituximab in patients with membranous nephropathy: A prospective study and a review of the literature. Autoimmun Rev 2016; 15.

15. Sciascia S, Talavera-Garcia E, Roccatello D, Baldovino S, Mengatti E, Cuadrado MJ. Upcoming biological therapies in systemic lupus erythematosus. Int Immunopharmacol 2015; 27.

16. Ruiz-Irastorza G, Ramos-Casals M, Brito-Zeron P, Khamashta MA. Clinical efficacy and side effects of antimalarials in systemic lupus erythematosus: a systematic review. Ann Rheum Dis 2010; 69: 20-8. 
Table 1: Characteristics of RCTs included in the systematic review

\begin{tabular}{|c|c|c|c|c|c|c|c|c|c|}
\hline $\begin{array}{c}\text { Study } \\
\text { (First } \\
\text { Author, } \\
\text { Year) }\end{array}$ & RTC & Country & Inclusion Criteria & Patients & $\begin{array}{c}\text { Age } \\
\text { mean(range) }\end{array}$ & $\begin{array}{c}\text { Time } \\
\text { receving } \\
\text { GCs }\end{array}$ & $\begin{array}{l}\text { Diseases } \\
\text { Duration of } \\
\text { SLE } \\
\text { mean(range) }\end{array}$ & $\begin{array}{l}\text { Steroids } \\
\text { (Oral or } \\
\text { IV) }\end{array}$ & GCs Protocol \\
\hline $\begin{array}{l}\text { Austin et } \\
\text { al. (2009) }\end{array}$ & $\begin{array}{l}\text { Randomized, } \\
\text { controlled trial of } \\
\text { prednisone, } \\
\text { cyclophosphamide, } \\
\text { and cyclosporine in } \\
\text { lupus membranous } \\
\text { nephropathy. }\end{array}$ & USA & $\begin{array}{l}\text { Membranous LN } \\
\text { with } \geq 2 \mathrm{~g} / \mathrm{d} \\
\text { proteinuria }\end{array}$ & $\begin{array}{l}42 \text { (15 in } \\
\text { the } \\
\text { prednisone } \\
\text { group) }\end{array}$ & $\begin{array}{l}40 \mathrm{yrs} \\
(13-60)\end{array}$ & $1 \mathrm{yr}$ & $\begin{array}{l}7 \text { months (1 - } \\
120)\end{array}$ & oral & $\begin{array}{l}\text { High-dosage } \\
\text { alternate-day oral } \\
\text { prednisone (initiated } \\
\text { at } 40 \mathrm{mg} / \mathrm{m}^{2} \text { body } \\
\text { surface area } \\
\text { [approximately } 1 \\
\mathrm{mg} / \mathrm{kg} \text { body wt] } \\
\text { every other day for } 8 \\
\mathrm{wk} \text {, followed by } \\
\text { gradual tapering [5 } \\
\mathrm{mg} / \mathrm{wk} \text { ] to } 10 \\
\mathrm{mg} / \mathrm{m} 2 \text { body surface } \\
\text { area every other day } \\
\text { for the remainder of } \\
\text { the } 1 \text {-yr protocol } \\
\text { treatment period) }\end{array}$ \\
\hline $\begin{array}{l}\text { Barile- } \\
\text { Fabris et } \\
\text { al. (2005) }\end{array}$ & $\begin{array}{l}\text { Controlled clinical } \\
\text { trial of IV } \\
\text { cyclophosphamide } \\
\text { versus IV } \\
\text { methylprednisolone } \\
\text { in severe } \\
\text { neurological } \\
\text { manifestations in } \\
\text { SLE. }\end{array}$ & Mexico & $\begin{array}{l}\text { NPSLE } \\
\text { manifestations* }\end{array}$ & $\begin{array}{l}32 \text { (Cy } \\
n=19 ; M P \\
n=13)\end{array}$ & $\begin{array}{l}\text { CyC arm: 33 } \\
\text { yrs (17-48); } \\
\text { MP arm: } \\
26 y r s \\
(19-44)\end{array}$ & $1 \mathrm{yr}$ & $\begin{array}{l}\text { CyC arm } 4.2 \\
(0.11-16) ; \\
\text { MP } 2.5(0- \\
12)\end{array}$ & $\begin{array}{l}\text { oral and } \\
\text { IV }\end{array}$ & $\begin{array}{l}\text { Basal prednisone } \\
\text { dose (mg/day) mean } \\
\text { (range): AT } \\
\text { BASELINE: Cy } 45 \\
(15-60) ; \text { MP } 45 \text { (15- } \\
60)\end{array}$ \\
\hline $\begin{array}{l}\text { Gourley } \\
\text { et al. } \\
(1996)\end{array}$ & $\begin{array}{l}\text { Methylprednisolone } \\
\text { and } \\
\text { cyclophosphamide, } \\
\text { alone or in } \\
\text { combination, in } \\
\text { patients with LN. }\end{array}$ & USA & $\mathrm{LN}$ & $\begin{array}{l}82 \\
\text { (MP arm, } \\
\mathrm{n}=27 ; \\
\mathrm{CyC} \text { arm, } \\
\mathrm{n}=27 ; \\
\mathrm{MP}+\mathrm{CyC} \\
\text { arm, } \mathrm{n}=28 \text { ) }\end{array}$ & $\begin{array}{l}\text { MP arm: 30; } \\
\text { CyC arm:30; } \\
\text { MP+CyC } \\
\text { arm: } 31\end{array}$ & $1 \mathrm{yr}$ & $\begin{array}{l}\text { MP arm: } 31 \pm \\
8.6 \text { months; } \\
\text { CyC arm: } 24 \\
\pm 6.9 \\
\text { months; } \\
\text { MP+CyC arm } \\
39 \pm 13.6 \\
\text { months }\end{array}$ & $\begin{array}{l}\text { oral and } \\
\text { iv }\end{array}$ & $\begin{array}{l}\text { IV: Bolus therapy } \\
\text { with MP }\left(1 \mathrm{~g} / \mathrm{m}^{2}\right. \\
\text { body surface area), } \\
\text { given monthly for at } \\
1 \text { year. } \\
\text { ORAL: } 0.5 \mathrm{mg} / \mathrm{kg} \text { per } \\
\text { day for } 4 \text { weeks. The } \\
\text { prednisone dose } \\
\text { was then tapered by } \\
5 \text { mg every other } \\
\text { day each } \\
\text { week to the minimal } \\
\text { dose of } 0.25 \mathrm{mg} / \mathrm{kg} \\
\text { every other day }\end{array}$ \\
\hline $\begin{array}{l}\text { Belmont } \\
\text { et al. } \\
(1995)\end{array}$ & $\begin{array}{l}\text { Misoprostol and } \\
\text { prednisone } \\
\text { treatment of LN. }\end{array}$ & USA & $\mathrm{LN}$ & 14 & $\begin{array}{l}35 \pm 2 \text { (range } \\
26-55)\end{array}$ & $\begin{array}{l}3 \\
\text { months }\end{array}$ & $\mathrm{N} / \mathrm{R}$ & oral & $\begin{array}{l}\text { Oral prednisone } 1 \\
\mathrm{mg} / \mathrm{kg} / \text { day during } 8 \\
\text { weeks. After that, } \\
\text { the steroid dose was } \\
\text { tapered by } 10 \mathrm{mg} \\
\text { every } 2 \text { weeks for } \\
\text { the next } 4 \text { weeks }\end{array}$ \\
\hline
\end{tabular}




\begin{tabular}{|c|c|c|c|c|c|c|c|c|c|}
\hline $\begin{array}{l}\text { Barron et } \\
\text { al. (1982) }\end{array}$ & $\begin{array}{l}\text { Pulse } \\
\text { methylprednisolone } \\
\text { therapy in diffuse } \\
\text { proliferative lupus } \\
\text { nephritis. }\end{array}$ & USA & $\mathrm{LN}$ & $\begin{array}{l}22 \text { (high } \\
\text { dose group } \\
n=15 ; \text { pulse } \\
\text { group } n=7 \text { ) }\end{array}$ & $N / R$ & $1 \mathrm{yr}$ & $\begin{array}{l}\text { Age of onset } \\
(y r): \text { pulse } \\
11.4 \pm 3.6 \\
\text { high dose } \\
11.9 \pm 2.9\end{array}$ & $\begin{array}{l}\text { oral and } \\
\text { IV }\end{array}$ & $\begin{array}{l}\text { HIGH-DOSE group: } \\
\text { prednisone oral } \\
\text { starting at } 2 \\
\mathrm{mg} / \mathrm{kg} / \text { day for a } 3-6 \\
\text { months and then } \\
\text { reduced gradually } \\
\text { over the next several } \\
\text { months. } \\
\text { PULSE group: } 6 \\
\text { times } 30 \mathrm{mg} / \mathrm{kg} \\
\text { body weight of } \\
\text { methylprednisolone } \\
\text { (maximum } 1 \mathrm{gm} \text { ) } \\
\text { followed by } \\
\text { prednisone } 2 \\
\text { mg/kg/day }\end{array}$ \\
\hline $\begin{array}{l}\text { Boumpas } \\
\text { et al. } \\
(1992)\end{array}$ & $\begin{array}{l}\text { Controlled trial of } \\
\text { pulse } \\
\text { methylprednisolone } \\
\text { versus two regimens } \\
\text { of pulse } \\
\text { cyclophosphamide in } \\
\text { severe lupus } \\
\text { nephritis }\end{array}$ & USA & Severe LN & 65 & $N / R$ & $\begin{array}{l}3 \\
\text { months }\end{array}$ & 33 months & IV & $\begin{array}{l}\text { IV of } 1.0 \mathrm{~g} / \mathrm{m} 2 \\
\text { methylprednisolone } \\
\text { over initially in three } \\
\text { daily doses, followed } \\
\text { by monthly single } \\
\text { doses } \\
\text { for } 6 \text { months }\end{array}$ \\
\hline $\begin{array}{l}\text { Edwards } \\
\text { et al. } \\
(1987)\end{array}$ & $\begin{array}{l}\text { Double blind } \\
\text { controlled trial of } \\
\text { methylprednisolone } \\
\text { infusions in SLE using } \\
\text { individualised } \\
\text { outcome assessment }\end{array}$ & UK & Severe SLE & 20 & $N / R$ & $\begin{array}{l}6 \\
\text { months }\end{array}$ & $N / R$ & IV & $\begin{array}{l}3 \text { daily infusions of } \\
\text { either } 100 \mathrm{mg} \text { or } 1 \mathrm{~g} \\
\text { of } \\
\text { methylprednisolone } \\
+ \text { a mean of } \\
7 \mathrm{mg} / \text { day prednisone }\end{array}$ \\
\hline $\begin{array}{l}\text { Hahn et } \\
\text { al. (1975) }\end{array}$ & $\begin{array}{l}\text { Azathioprine plus } \\
\text { prednisone } \\
\text { compared with } \\
\text { prednisone alone in } \\
\text { the treatment of } \\
\text { SLE. Report of a } \\
\text { prospective } \\
\text { controlled trial in } 24 \\
\text { patients }\end{array}$ & USA & Severe SLE & 13 & 31 & $\begin{array}{l}3 \\
\text { months }\end{array}$ & $N / R$ & oral & $\begin{array}{l}\text { Prednisolone } 60 \\
\mathrm{mg} / \text { day }\end{array}$ \\
\hline
\end{tabular}

GCs, glucorticoids; LN, lupus nephritis; SLE, Systemic Lupus Erythematosus; NPSLE, Neuropsychiatric Systemic Lupus Erythematosus ; IV, intravenous infusion; CyC, cyclophosphamide; MP, methylprednisolone; N/R, not reported; *peripheral/cranial neuropathy, optic neuritis, transverse myelitis, brainstem disease, refractory seizures or coma 
Table 2: Adverse Effects reported in each RTC included in the systematic review

\begin{tabular}{|c|c|c|c|c|c|}
\hline $\begin{array}{l}\text { Study (First } \\
\text { Author, Year) }\end{array}$ & $\begin{array}{l}\text { Patients } \\
\text { Receiving } \\
\text { CGs } \\
\text { alone }\end{array}$ & Diabetes/Hyperglycaemia & Infections & $\begin{array}{c}\text { Avascular necrosis } \\
\text { of the hip }\end{array}$ & Other AEs \\
\hline $\begin{array}{l}\text { Austin et al. } \\
\text { (2009) }\end{array}$ & 15 & 1 Diabetes & $\begin{array}{l}1 \text { pneumonia, } 3 \\
\text { other infections* }\end{array}$ & $4^{* *}$ & N/A \\
\hline $\begin{array}{l}\text { Barile-Fabris } \\
\text { et al. (2005) }\end{array}$ & 13 & 1 Hyperglycaemia & $\begin{array}{l}8 \text { Urinary tract and } 4 \\
\text { respiratory } \\
\text { infections }\end{array}$ & $N / R$ & Pancreatitis \\
\hline $\begin{array}{l}\text { Gourley et al. } \\
\text { (1996) }\end{array}$ & 27 & $N / R$ & $\begin{array}{l}1 \text { herpes zoster, } 2 \\
\text { other infections }\end{array}$ & $\begin{array}{l}6 \text { Avascular } \\
\text { Necrosis }\end{array}$ & 2 Amenorrhea \\
\hline $\begin{array}{l}\text { Belmont et } \\
\text { al. (1995) }\end{array}$ & 7 & $\mathrm{~N} / \mathrm{R}$ & 1 & $\mathrm{~N} / \mathrm{R}$ & N/A \\
\hline $\begin{array}{l}\text { Barron et al. } \\
\quad(1982)\end{array}$ & 22 & $N / R$ & $\mathrm{~N} / \mathrm{R}$ & 3 Aseptic necrosis & N/A \\
\hline $\begin{array}{l}\text { Boumpas et } \\
\text { al. (1992) }\end{array}$ & 65 & $N / R$ & 3 herpes zoster & $\begin{array}{c}3 / 17 \\
\text { osteonecrosis }\end{array}$ & 6 cataracts \\
\hline $\begin{array}{l}\text { Edwards et } \\
\text { al. (1987) }\end{array}$ & 20 & $\begin{array}{l}\text { Raised serum glucose } \\
\text { levels were } \\
\text { transient and not } \\
\text { associated with } \\
\text { symptoms. }\end{array}$ & $N / R$ & $\mathrm{~N} / \mathrm{R}$ & $\begin{array}{c}\text { Blood pressure rose temporarily in } \\
\text { some patients } \\
\text { but did not require treatment }\end{array}$ \\
\hline $\begin{array}{l}\text { Hahn et al. } \\
\qquad(1975)\end{array}$ & 13 & 7 hyperglycaemia & 7 & 1 Aseptic necrosis & $\begin{array}{l}11 \text { Cushingoid habitus; } 11 \\
\text { hypertension; } 6 \text { hypokalemia }\end{array}$ \\
\hline
\end{tabular}

GCs, glucorticoids; N/R, not reported; *other infections included sinusitis, bronchitis, otitis media, dental abscess, upper respiratory tract infection, sty, pelvic inflammatory disease, cholecystitis, and herpes simplex virus skin infection); ** not distinguishing between severe osteoporosis/avascular necrosis of the hip 
